Article

\title{
Comparative Analysis of Skeletal Muscle Metabolites of Fish with Various Rates of Aging
}

\author{
Dmitry L. Maslov *, Oxana P. Trifonova, Anton N. Mikhailov, Konstantin V. Zolotarev, \\ Kirill V. Nakhod, Valeriya I. Nakhod, Nataliya F. Belyaeva, Marina V. Mikhailova, Petr G. Lokhov \\ and Alexander I. Archakov
}

Institute of Biomedical Chemistry, 10 building 8, Pogodinskaya street, Moscow 119121, Russia oxana.trifonova@gmail.com (O.P.T.); myhas84@mail.ru (A.N.M.); fireaxe@mail.ru (K.V.Z.); g-s2011@mail.ru (K.V.N.); kardavaleriya@yandex.ru (V.I.N.); natalia.belyaeva@ibmc.msk.ru (N.F.B.); m_mikhailova@mail.ru (M.V.M.); lokhovpg@rambler.ru (P.G.L.); alexander.archakov@ibmc.msk.ru (A.I.A.)

* Correspondence: dlmaslov@mail.ru; Tel.: +7-499-246-6980

Received: 28 December 2018; Accepted: 23 March 2019; Published: 31 March 2019

\begin{abstract}
Fish species exhibit great diversity rating of aging (from negligible to rapid), which gives a unique possibility for the discovery of the molecular mechanisms that determine the differences in the rate of aging. A mass spectrometric metabolic profiling of skeletal muscle of fish with various aging rates was carried out by direct injection to a quadrupole time-of-flight mass spectrometer. The first group includes long-lived fish species (pike (Esox Lucius) and sterlet (Acipenser ruthenus); the second group-species with gradual senescence such as that observed in many mammalian species of similar size (zander (Sandra lucioperca) and perch (Perca fluviatilis)) and the third group-species with very short life cycle (chum salmon (Oncorhynchus keta) and pink salmon (Oncorhynchus gorbuscha)). Multivariate analysis of metabolic profiles allowed the detecting of about 80 group-specific features associated with amino acids, lipids, biogenic amines, intermediates of glycolysis, glycogenolysis, and citric acid cycle. Possible roles in the aging process are hypothesized for the biochemical pathways of the metabolites that were altered in the different groups.
\end{abstract}

Keywords: aging; metabolome profiling; muscle; fish

\section{Introduction}

A great range of ages is observed among different animals, including various species of fish. Some fish species (rockfish, sturgeon) has not revealed any age-related decline in their physiological capacity (including reproduction) for several decades of observation. The life cycle of other species (genus nothobranchius) is very short and does not exceed several weeks even in protected environments $[1,2]$. During the investigation of the aging process in animals, C. Finch has proposed to divide organisms into three categories differing in the rate of aging: negligible (long-lived species), gradual (species whose aging rate is similar to mammal species), and rapid (species with very short life cycle) [3]. According to the Finch's criteria, the main signs of negligible aging are continuous growth (although slow in most cases), the absence of an age-related increase in mortality rate, the absence of a decline in physiological capacity (including reproductive capacity) and disease resistance [3]. Sterlet, as well as flatfish, beluga, and rockfish, were classified as species with negligible aging [4]. Pike (Esox Lucius) can also be attributed to the same group [5]. Such species as guppy, red panchax, medaka, platyfish, Indian murrel, zander, and perch exhibit gradual senescence, which is typical for most vertebrates $[4,6]$. The age-related decline of regenerative ability, increasing the probability of physiological damages with advancing age, is an attribute of these species [5]. 
Finally, the last group (rapid aging) is characterized by rapid senescence with more or less synchronous deterioration of physiological capacity of all organs of an organism. Such species often die after spawning. Lampreys, eels, and Pacific salmonids may be included in this category.

The observable diversity in the lifespan among fish species provides an opportunity for the investigation of mechanisms responsible for dramatic differences in the rate of aging [7]. The long-lived species (negligibly senescent) may be considered as original antiaging models. Investigation of these species may facilitate determination of the pathways that protect effectively against the degenerative process. On the contrary, rapidly senescent species may be considered as models of accelerated aging. Comprehensive research of the species can help identify mechanisms associated with the fast development of age-related pathologies [8,9].

A progressive decrease of muscle mass and strength leading to deterioration of physiological functions of an organism, as well as the development of age-related disorders are one of the most notable factors of aging [10]. Skeletal muscles play a key role in the maintenance of healthy and active lifestyle since they are involved in many essential functions: control of movement and pose, physical function, participation in metabolism (for example, skeletal muscles are critical for the maintenance of glycaemic level), etc. [11-13]. Unfortunately, our knowledge about the pathophysiology of the loss of muscle mass and strength is still limited [14].

A metabolomics-based investigation of the skeletal muscle of the three fish groups with different aging rate was performed: the first group consists of biosamples of negligibly senescent species (pike (Esox lucius) and sterlet (Acipenser ruthenus), the second group-biosamples of gradually senescent species (zander (Sander lucioperca) and perch (Perca fluviatilis), and the third one includes biosamples of rapidly senescent species (chum salmon (Oncorhynchus keta), and pink salmon (Oncorhynchus gorbuscha). Comparative analysis of untargeted metabolomics data allows detecting the group-specific features. Subsequent analysis of the selected features enables the removal of artifacts, identify metabolites and detect pathways, in which the metabolites may be involved. An investigation of the contribution of these pathways to the functioning of the organism may provide insights into biological mechanisms related to the processes of maintenance of muscle mass and development of degenerative process [15].

\section{Results}

The method of Direct-Injection Electrospray Ionization Mass Spectrometry (DI-ESI-MS) was used in the study. An application of an untargeted approach enabled the detection of about 4000 different $m / z$ ions. Multivariate analysis of metabolic data was performed after normalization and the removal of artifacts and outliers. Metabolite ions that were found at least in $70 \%$ of samples in each of the compared groups were admitted to the analysis. Principal component analysis of mass spectrometry spectra allowed validating the presence of significant differences in metabolic composition between samples related to different groups (Figure 1). A Kruskal-Wallis $\mathrm{H}$ test reconfirmed the results and enabled to detect features, the intensity of which was significantly different $(p<0.05)$ in the compared groups. It should be noted that no significant gender differences in the metabolic profiles were revealed (data not shown).

About 80 statistical significant features $(p<0.05)$ were detected by the comparative analysis. Results of the putative identification of the features showed that they are amino acids, biogenic amines, carnitines, intermediates of glycolysis, glycogenolysis, citric acid cycle, and lipid metabolism (Table 1). The identification of the metabolites was carried out by using two orthogonal characteristics (accurate mass and isotopic abundance distribution) that satisfy level 2 (putatively annotated compounds) according to the Metabolomics Standards Initiative (MSI) requirements (http:/ / www.metabolomicsmsi.org/). It should be noted that some masses were redundant-they have several candidates. The candidates have identical brutto-formula and, consequently, identical isotope distribution that does not permit proper differentiating by the method of metabolite identification applied in this study. However, these candidates belong to the same compound classes that meet the level 3 of metabolite identification (putatively annotated compound classes) [16]. The further consideration 
of such metabolites represented the authors' point of view based on previously published results of identification.

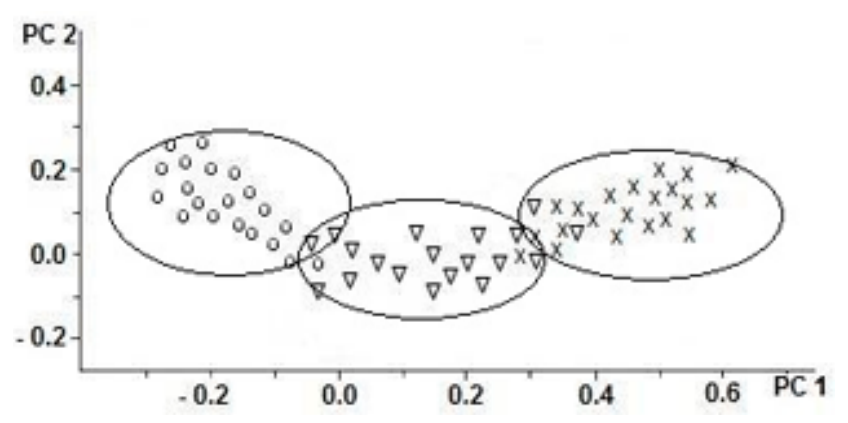

Figure 1. The Principal Component Analysis (PCA) score plot of mass spectrometry spectra illustrates the clustering of samples according to attributed group membership (negligible $(\times)$, gradual $(\Delta)$, and rapid aging $(\mathrm{O})$ ), with more than $80 \%$ of total variance (the first two components). The clustering displays a difference in the metabolic composition between the compared groups.

For more specific identification, a tandem mass spectrometry (MS/MS) method was applied. Metabolites of great biological significance (observed mainly in the samples related to negligible and gradual senescence) and whose concentration exceeded the limits of the method were selected for the analysis. Figure 2 shows the fragment list resulting from MS/MS fragmentation of selected metabolite $(m / z-162,1150)$.

L-Carnitine (MS/MS $10 \mathrm{eV}$ )

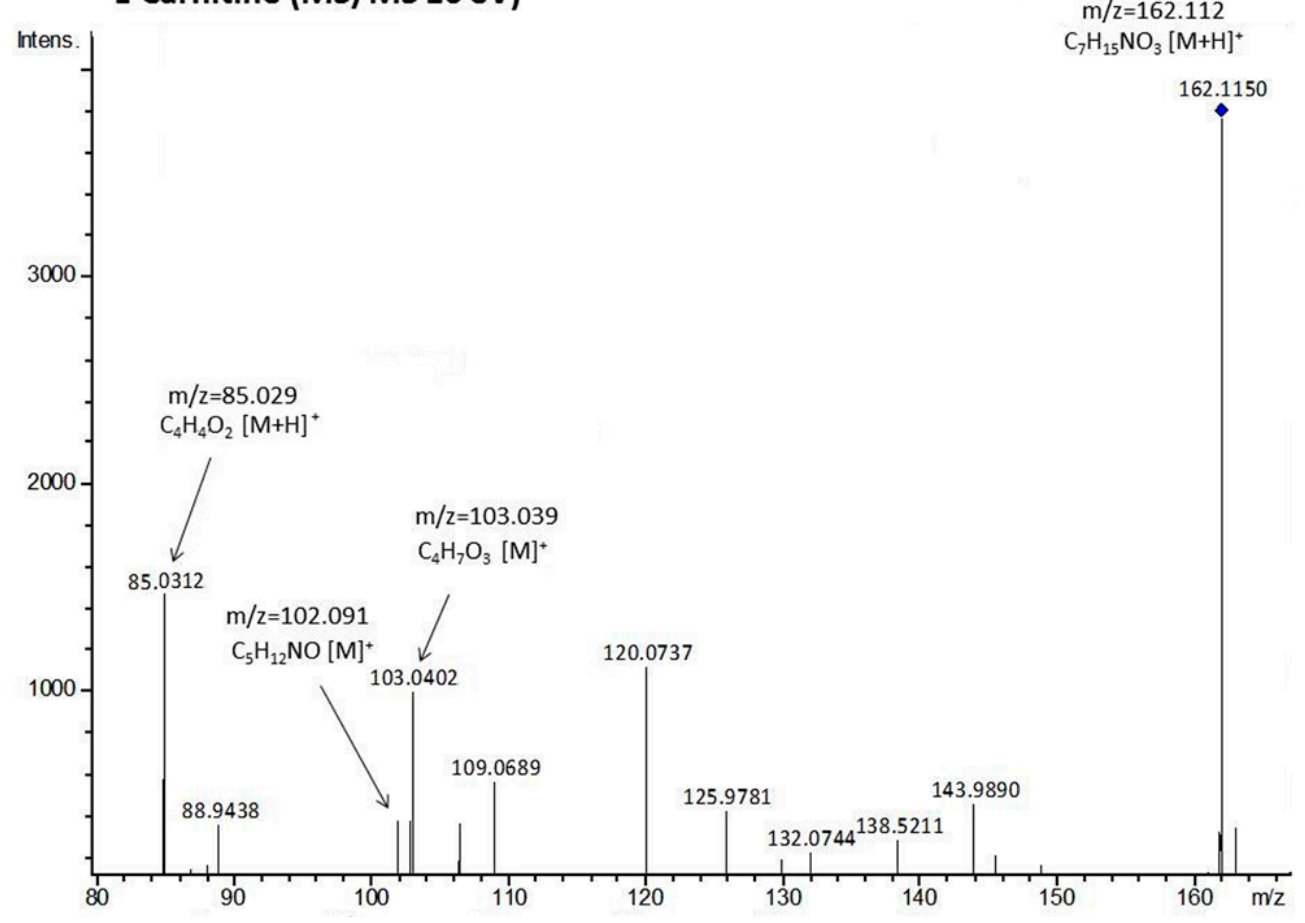

Figure 2. The results of tandem mass spectrometry (MS/MS) fragmentation of selected metabolites $(m / z-162,1150)$. MS/MS spectra obtained in positive ionization mode. Collision energy-10 eV. Reference $m / z$ value of fragments of l-carnitine, chemical formula and ion type (taken from the public metabolite database) are also indicated in the figure.

Figure 3 shows fragment list resulting from MS/MS fragmentation of selected metabolites $(m / z-132,0777$ and $m / z-132,1024)$. 
Table 1. Distinctive $m / z$ features and putatively identified skeletal muscle metabolites typical for fish species with different lifespan.

\begin{tabular}{|c|c|c|c|c|c|c|c|}
\hline \multirow[b]{2}{*}{ No } & \multicolumn{7}{|c|}{ Mass of Ion } \\
\hline & Metabolite & HMDB ID & Measured $(m / z)$ & Calculated $(\mathrm{m} / \mathrm{z})$ & Monoisotopic Mol Weight (Da) & Ion Form & Elemental Composition \\
\hline \multicolumn{8}{|c|}{ metabolites a high level of which was observed in the samples relating to negligible } \\
\hline 1 & hypotaurine & HMDB00965 & 110,0175 & 110,027 & 110,0275 & $\mathrm{M}+\mathrm{H}$ & $\mathrm{C}_{2} \mathrm{H}_{7} \mathrm{NO}_{2} \mathrm{~S}$ \\
\hline 2 & creatinine & HMDB00562 & 114,0634 & 114,0661 & 113,0589 & $\mathrm{M}+\mathrm{H}$ & $\mathrm{C}_{4} \mathrm{H}_{7} \mathrm{~N}_{3} \mathrm{O}$ \\
\hline 3 & creatinine & HMDB00562 & 136,0027 & 136,0481 & 113,0589 & $\mathrm{M}+\mathrm{Na}$ & $\mathrm{C}_{4} \mathrm{H}_{7} \mathrm{~N}_{3} \mathrm{O}$ \\
\hline 4 & L-carnitine & HMDB00062 & 162,1123 & 162,1124 & 161,10519 & $\mathrm{M}+\mathrm{H}$ & $\mathrm{C}_{7} \mathrm{H}_{15} \mathrm{NO}_{3}$ \\
\hline 5 & $\mathrm{n} / \mathrm{a}$ & - & 635,3064 & - & - & - & - \\
\hline 6 & $\mathrm{PC}^{*}$ & HMDB08531 & 844,6487 & 844,679 & 843,6717 & $\mathrm{M}+\mathrm{H}$ & $\mathrm{C}_{48} \mathrm{H}_{94} \mathrm{NO}_{8} \mathrm{P}$ \\
\hline \multicolumn{8}{|c|}{ metabolites a high level of which was observed in the samples relating to negligible and gradual } \\
\hline 7 & alanine & HMDB00161 & 90,0518 & 90,0549 & 89,04767 & $\mathrm{M}+\mathrm{H}$ & $\mathrm{C}_{3} \mathrm{H}_{7} \mathrm{NO}_{2}$ \\
\hline 8 & alanine & HMDB00161 & 112,0307 & 112,0368 & 89,04767 & $\mathrm{M}+\mathrm{Na}$ & $\mathrm{C}_{3} \mathrm{H}_{7} \mathrm{NO}_{2}$ \\
\hline 9 & valine & HMDB00883 & 118,0851 & 118,0862 & 117,0789 & $\mathrm{M}+\mathrm{H}$ & $\mathrm{C}_{5} \mathrm{H}_{11} \mathrm{NO}_{2}$ \\
\hline 10 & sarcosine & HMDB00271 & 128,0106 & 128,0108 & 89,04767 & $\mathrm{M}+\mathrm{K}$ & $\mathrm{C}_{3} \mathrm{H}_{7} \mathrm{NO}_{2}$ \\
\hline 11 & taurine & HMDB00251 & 126,0186 & 126,0219 & 125,0146 & $\mathrm{M}+\mathrm{H}$ & $\mathrm{C}_{2} \mathrm{H}_{7} \mathrm{NO}_{3} \mathrm{~S}$ \\
\hline 12 & creatine & HMDB00064 & 132,0764 & 132,0767 & 131,0694 & $\mathrm{M}+\mathrm{H}$ & $\mathrm{C}_{4} \mathrm{H}_{9} \mathrm{~N}_{3} \mathrm{O}_{2}$ \\
\hline 13 & leucine & HMDB00687 & 132,1024 & 132,1019 & 131,0946 & $\mathrm{M}+\mathrm{H}$ & $\mathrm{C}_{6} \mathrm{H}_{13} \mathrm{NO}_{2}$ \\
\hline 14 & valine & HMDB00883 & 140,0617 & 140,0681 & 117,0789 & $\mathrm{M}+\mathrm{Na}$ & $\mathrm{C}_{5} \mathrm{H}_{11} \mathrm{NO}_{2}$ \\
\hline 15 & taurine & HMDB00251 & 147,9842 & 148,0038 & 125,0146 & $\mathrm{M}+\mathrm{Na}$ & $\mathrm{C}_{2} \mathrm{H}_{7} \mathrm{NO}_{3} \mathrm{~S}$ \\
\hline 16 & creatine & HMDB00064 & 154,0571 & 154,0586 & 131,0694 & $\mathrm{M}+\mathrm{Na}$ & $\mathrm{C}_{4} \mathrm{H}_{9} \mathrm{~N}_{3} \mathrm{O}_{2}$ \\
\hline 17 & spermidine & HMDB01257 & 146,1466 & 146,1651 & 145,1578 & $\mathrm{M}+\mathrm{H}$ & $\mathrm{C}_{7} \mathrm{H}_{19} \mathrm{~N}_{3}$ \\
\hline 18 & maleylacetate & HMDB60348 & 159,0280 & 159,0288 & 158,0215 & $\mathrm{M}+\mathrm{H}$ & $\mathrm{C}_{6} \mathrm{H}_{6} \mathrm{O}_{5}$ \\
\hline 19 & leucine & HMDB00687 & 170,0253 & 170,0577 & 131,0946 & $\mathrm{M}+\mathrm{K}$ & $\mathrm{C}_{6} \mathrm{H}_{13} \mathrm{NO}_{2}$ \\
\hline 20 & maleylacetate & HMDB60348 & 196,9787 & 196,9847 & 158,0215 & $\mathrm{M}+\mathrm{K}$ & $\mathrm{C}_{6} \mathrm{H}_{6} \mathrm{O}_{5}$ \\
\hline 21 & $\mathrm{n} / \mathrm{a}$ & - & 713,4983 & - & - & - & - \\
\hline
\end{tabular}


Table 1. Cont

\begin{tabular}{|c|c|c|c|c|c|c|c|}
\hline \multirow[b]{2}{*}{ № } & \multicolumn{7}{|c|}{ Mass of Ion } \\
\hline & Metabolite & HMDB ID & Measured $(m / z)$ & Calculated $(\mathrm{m} / \mathrm{z})$ & Monoisotopic Mol Weight (Da) & Ion Form & Elemental Composition \\
\hline \multicolumn{8}{|c|}{ metabolites a high level of which was observed in the samples relating to gradual } \\
\hline 22 & itaconic acid & HMDB02092 & 152,9764 & 153,0158 & 130,0266 & $\mathrm{M}+\mathrm{Na}$ & $\mathrm{C}_{5} \mathrm{H}_{6} \mathrm{O}_{4}$ \\
\hline 23 & $\mathrm{n} / \mathrm{a}$ & - & 771,6006 & - & - & - & - \\
\hline 24 & $P C^{*}$ & HMDB08136 & 802,5179 & 802,5357 & 779,5465 & $\mathrm{M}+\mathrm{Na}$ & $\mathrm{C}_{44} \mathrm{H}_{78} \mathrm{NO}_{8} \mathrm{P}$ \\
\hline 25 & $\mathrm{PC}^{*}$ & HMDB08138 & 804,5363 & 804,5513 & 781,5621 & $\mathrm{M}+\mathrm{Na}$ & $\mathrm{C}_{44} \mathrm{H}_{80} \mathrm{NO}_{8} \mathrm{P}$ \\
\hline 26 & $\mathrm{PC}^{*}$ & HMDB08136 & 822,5332 & 822,5410 & 783,5778 & $\mathrm{M}+\mathrm{K}$ & $\mathrm{C}_{44} \mathrm{H}_{82} \mathrm{NO}_{8} \mathrm{P}$ \\
\hline 27 & $\mathrm{PC}^{*}$ & HMDB08589 & 826,6635 & 826,6684 & 825,6611 & $\mathrm{M}+\mathrm{H}$ & $\mathrm{C}_{48} \mathrm{H}_{92} \mathrm{NO}_{7} \mathrm{P}$ \\
\hline 28 & $\mathrm{PC}^{*}$ & HMDB08304 & 832,5702 & 832,5827 & 809,5934 & $\mathrm{M}+\mathrm{Na}$ & $\mathrm{C}_{46} \mathrm{H}_{84} \mathrm{NO}_{8} \mathrm{P}$ \\
\hline 29 & $\mathrm{PC}^{*}$ & HMDB08272 & 834,5845 & 834,5983 & 811,6091 & $\mathrm{M}+\mathrm{Na}$ & $\mathrm{C}_{46} \mathrm{H}_{86} \mathrm{NO}_{8} \mathrm{P}$ \\
\hline 30 & $P C^{*}$ & HMDB08467 & 844,5150 & 844,5253 & 805,5621 & $\mathrm{M}+\mathrm{K}$ & $\mathrm{C}_{46} \mathrm{H}_{80} \mathrm{NO}_{8} \mathrm{P}$ \\
\hline \multicolumn{8}{|c|}{ metabolites a high level of which was observed in the samples relating to rapid } \\
\hline 31 & $\mathrm{n} / \mathrm{a}$ & - & 100,1074 & - & - & - & - \\
\hline 32 & serine & HMDB00187 & 106,0391 & 106,0498 & 105,0425 & $\mathrm{M}+\mathrm{H}$ & $\mathrm{C}_{3} \mathrm{H}_{7} \mathrm{NO}_{3}$ \\
\hline 33 & pyruvate & HMDB00243 & 110,996 & 111,0053 & 88,01604 & $\mathrm{M}+\mathrm{Na}$ & $\mathrm{C}_{3} \mathrm{H}_{4} \mathrm{O}_{3}$ \\
\hline 34 & lactic acid & HMDB00190 & 113,0268 & 113,0209 & 90,03169 & $\mathrm{M}+\mathrm{Na}$ & $\mathrm{C}_{3} \mathrm{H}_{6} \mathrm{O}_{3}$ \\
\hline 35 & cysteine & HMDB00574 & 122,0211 & 122,0270 & 121,0197 & $\mathrm{M}+\mathrm{H}$ & $\mathrm{C}_{3} \mathrm{H}_{7} \mathrm{NO}_{2} \mathrm{~S}$ \\
\hline 36 & choline & HMDB00097 & 127,0841 & 127,0967 & 104,1075 & $\mathrm{M}+\mathrm{Na}$ & $\mathrm{C}_{5} \mathrm{H}_{14} \mathrm{NO}$ \\
\hline 37 & lactic acid & HMDB00190 & 128,9881 & 128,9948 & 90,03169 & $\mathrm{M}+\mathrm{K}$ & $\mathrm{C}_{3} \mathrm{H}_{6} \mathrm{O}_{3}$ \\
\hline 38 & $\mathrm{n} / \mathrm{a}$ & - & 137,1283 & - & - & - & - \\
\hline 39 & fumaric acid & HMDB00134 & 138,9945 & 139,0002 & 116,0109 & $\mathrm{M}+\mathrm{Na}$ & $\mathrm{C}_{4} \mathrm{H}_{4} \mathrm{O}_{4}$ \\
\hline 40 & niacinamide & HMDB01406 & 145,0250 & 145,0372 & 122,048 & $\mathrm{M}+\mathrm{Na}$ & $\mathrm{C}_{6} \mathrm{H}_{6} \mathrm{~N}_{2} \mathrm{O}$ \\
\hline 41 & malate & HMDB00156 & 156,998 & 157,0107 & 134,0215 & $\mathrm{M}+\mathrm{Na}$ & $\mathrm{C}_{4} \mathrm{H}_{6} \mathrm{O}_{5}$ \\
\hline 42 & $\alpha$-ketoglutarate & HMDB00208 & 168,9989 & 169,0107 & 146,0215 & $\mathrm{M}+\mathrm{Na}$ & $\mathrm{C}_{5} \mathrm{H}_{6} \mathrm{O}_{5}$ \\
\hline
\end{tabular}


Table 1. Cont

\begin{tabular}{|c|c|c|c|c|c|c|c|}
\hline \multirow[b]{2}{*}{ № } & \multicolumn{7}{|c|}{ Mass of Ion } \\
\hline & Metabolite & HMDB ID & Measured $(m / z)$ & Calculated $(\mathrm{m} / \mathrm{z})$ & Monoisotopic Mol Weight (Da) & Ion Form & Elemental Composition \\
\hline 43 & serinyl-alanine & HMDB29032 & 177,0656 & 177,0869 & 176,0797 & $\mathrm{M}+\mathrm{H}$ & $\mathrm{C}_{6} \mathrm{H}_{12} \mathrm{~N}_{2} \mathrm{O}_{4}$ \\
\hline 44 & methylenesuccinic acid & HMDB59762 & 180,9791 & 180,9898 & 142,0266 & $\mathrm{M}+\mathrm{K}$ & $\mathrm{C}_{6} \mathrm{H}_{6} \mathrm{O}_{4}$ \\
\hline 45 & $\alpha$-ketoglutarate & HMDB00208 & 184,9788 & 184,9846 & 146,0215 & $\mathrm{M}+\mathrm{K}$ & $\mathrm{C}_{5} \mathrm{H}_{6} \mathrm{O}_{5}$ \\
\hline 46 & threoninyl-alanine & HMDB29054 & 191,0972 & 191,1026 & 190,0953 & $\mathrm{M}+\mathrm{H}$ & $\mathrm{C}_{7} \mathrm{H}_{14} \mathrm{~N}_{2} \mathrm{O}_{4}$ \\
\hline 47 & serinyl-alanine & HMDB29032 & 190,0210 & 190,0689 & 176,0797 & $\mathrm{M}+\mathrm{Na}$ & $\mathrm{C}_{6} \mathrm{H}_{12} \mathrm{~N}_{2} \mathrm{O}_{4}$ \\
\hline 48 & citric acid & HMDB00094 & 215,0120 & 215,0162 & 192,0270 & $\mathrm{M}+\mathrm{Na}$ & $\mathrm{C}_{6} \mathrm{H}_{8} \mathrm{O}_{7}$ \\
\hline 49 & $\mathrm{n} / \mathrm{a}$ & - & 227,1875 & - & - & - & - \\
\hline 50 & tridecanoic acid & HMDB00910 & 237,1446 & 237,1825 & 214,1932 & $\mathrm{M}+\mathrm{Na}$ & $\mathrm{C}_{13} \mathrm{H}_{26} \mathrm{O}_{2}$ \\
\hline 51 & palmitoleic acid & HMDB03229 & 279,2001 & 279,2294 & 256,2402 & $\mathrm{M}+\mathrm{Na}$ & $\mathrm{C}_{16} \mathrm{H}_{30} \mathrm{O}_{2}$ \\
\hline 52 & $\mathrm{n} / \mathrm{a}$ & - & 285,2529 & - & - & - & - \\
\hline 53 & linolenic acid & HMDB013 & 301,1796 & 301,2138 & 278,2245 & $\mathrm{M}+\mathrm{Na}$ & $\mathrm{C}_{18} \mathrm{H}_{30} \mathrm{O}_{2}$ \\
\hline 54 & linoleic acid & HMDB00673 & 303,2024 & 303,2294 & 280,2402 & $\mathrm{M}+\mathrm{Na}$ & $\mathrm{C}_{18} \mathrm{H}_{32} \mathrm{O}_{2}$ \\
\hline 55 & oleic acid & HMDB020 & 305,2036 & 305,2451 & 282,2558 & $\mathrm{M}+\mathrm{Na}$ & $\mathrm{C}_{18} \mathrm{H}_{34} \mathrm{O}_{2}$ \\
\hline 56 & linolenic acid & HMDB013 & 317,1567 & 317,1877 & 278,2245 & $\mathrm{M}+\mathrm{K}$ & $\mathrm{C}_{18} \mathrm{H}_{30} \mathrm{O}_{2}$ \\
\hline 57 & linoleic acid & HMDB00673 & 319,1922 & 319,2033 & 280,2402 & $\mathrm{M}+\mathrm{K}$ & $\mathrm{C}_{18} \mathrm{H}_{32} \mathrm{O}_{2}$ \\
\hline 58 & eicosapentaenoic acid & HMDB01999 & 325,2039 & 325,2138 & 302,2245 & $\mathrm{M}+\mathrm{Na}$ & $\mathrm{C}_{20} \mathrm{H}_{30} \mathrm{O}_{2}$ \\
\hline 59 & eicosapentaenoic acid & HMDB01999 & 341,1619 & 341,1877 & 302,2245 & $\mathrm{M}+\mathrm{K}$ & $\mathrm{C}_{20} \mathrm{H}_{30} \mathrm{O}_{2}$ \\
\hline 60 & eicosadienoic acid & HMDB05060 & 347,2045 & 347,2346 & 308,2715 & $\mathrm{M}+\mathrm{K}$ & $\mathrm{C}_{20} \mathrm{H}_{36} \mathrm{O}_{2}$ \\
\hline 61 & docosahexaenoic acid & HMDB00021 & 351,2073 & 351,2294 & 328,2402 & $\mathrm{M}+\mathrm{Na}$ & $\mathrm{C}_{22} \mathrm{H}_{32} \mathrm{O}_{2}$ \\
\hline 62 & docosatrienoic acid & HMDB02823 & 357,2388 & 357,2764 & 334,2871 & $\mathrm{M}+\mathrm{Na}$ & $\mathrm{C}_{22} \mathrm{H}_{38} \mathrm{O}_{2}$ \\
\hline 63 & $\mathrm{~d}$-maltose & HMDB00163 & 365,0830 & 365,1054 & 342,1162 & $\mathrm{M}+\mathrm{Na}$ & $\mathrm{C}_{12} \mathrm{H}_{22} \mathrm{O}_{11}$ \\
\hline 64 & $\mathrm{MG}^{*}$ & HMDB11539 & 375,2064 & 375,2505 & 352,2613 & $\mathrm{M}+\mathrm{Na}$ & $\mathrm{C}_{21} \mathrm{H}_{36} \mathrm{O}_{4}$ \\
\hline 65 & $\mathrm{MG}^{*}$ & HMDB00115 & 379,2473 & 379,2818 & 356,2926 & $\mathrm{M}+\mathrm{Na}$ & $\mathrm{C}_{21} \mathrm{H}_{40} \mathrm{O}_{4}$ \\
\hline 66 & tetradecenoylcarnitine & HMDB02014 & 392,2518 & 392,2771 & 369,2879 & $\mathrm{M}+\mathrm{Na}$ & $\mathrm{C}_{21} \mathrm{H}_{39} \mathrm{NO}_{4}$ \\
\hline
\end{tabular}


Table 1. Cont.

\begin{tabular}{|c|c|c|c|c|c|c|c|}
\hline \multirow[b]{2}{*}{ № } & \multicolumn{7}{|c|}{ Mass of Ion } \\
\hline & Metabolite & HMDB ID & Measured $(m / z)$ & Calculated $(\mathrm{m} / \mathrm{z})$ & Monoisotopic Mol Weight (Da) & Ion Form & Elemental Composition \\
\hline 67 & $\mathrm{MG}^{*}$ & HMDB11547 & 419,2218 & 419,2558 & 380,2926 & $\mathrm{M}+\mathrm{K}$ & $\mathrm{C}_{23} \mathrm{H}_{40} \mathrm{O}_{4}$ \\
\hline 68 & hydroxycholesterol & HMDB02103 & 425,3057 & 425,339 & 402,3497 & $\mathrm{M}+\mathrm{Na}$ & $\mathrm{C}_{27} \mathrm{H}_{46} \mathrm{O}_{2}$ \\
\hline 69 & $\mathrm{MG}^{*}$ & HMDB11551 & 437,3341 & 437,3601 & 414,3709 & $\mathrm{M}+\mathrm{Na}$ & $\mathrm{C}_{25} \mathrm{H}_{50} \mathrm{O}_{4}$ \\
\hline 70 & $\mathrm{LPA}^{*}$ & HMDB07854 & 439,2501 & 439,2819 & 438,2746 & $\mathrm{M}+\mathrm{H}$ & $\mathrm{C}_{21} \mathrm{H}_{43} \mathrm{O}_{7} \mathrm{P}$ \\
\hline 71 & $\mathrm{n} / \mathrm{a}$ & - & 445,0474 & - & - & - & - \\
\hline 72 & $\mathrm{PA} *$ & HMDB11144 & 447,2502 & 447,2845 & 424,2953 & $\mathrm{M}+\mathrm{Na}$ & $\mathrm{C}_{21} \mathrm{H}_{45} \mathrm{O}_{6} \mathrm{P}$ \\
\hline 73 & LPA * & HMDB07855 & 459,2192 & 459,2482 & 436,2589 & $\mathrm{M}+\mathrm{Na}$ & $\mathrm{C}_{21} \mathrm{H}_{41} \mathrm{O}_{7} \mathrm{P}$ \\
\hline 74 & LysoPC * & HMDB10379 & 468,2750 & 468,3084 & 467,3011 & $\mathrm{M}+\mathrm{H}$ & $\mathrm{C}_{22} \mathrm{H}_{46} \mathrm{NO}_{7} \mathrm{P}$ \\
\hline 75 & LysoPC* & HMDB10383 & 494,3033 & 494,3241 & 493,3168 & $\mathrm{M}+\mathrm{H}$ & $\mathrm{C}_{24} \mathrm{H}_{48} \mathrm{NO}_{7} \mathrm{P}$ \\
\hline 76 & $\mathrm{n} / \mathrm{a}$ & - & 538,4796 & - & - & - & - \\
\hline 77 & $\mathrm{n} / \mathrm{a}$ & - & 551,3859 & - & - & - & - \\
\hline 78 & $\mathrm{DG}^{*}$ & HMDB56009 & 591,4606 & 591,4959 & 568,5066 & $\mathrm{M}+\mathrm{Na}$ & $\mathrm{C}_{35} \mathrm{H}_{68} \mathrm{O}_{5}$ \\
\hline 79 & $\mathrm{DG}^{*}$ & HMDB56010 & 619,4817 & 619,5272 & 596,5379 & $\mathrm{M}+\mathrm{Na}$ & $\mathrm{C}_{37} \mathrm{H}_{72} \mathrm{O}_{5}$ \\
\hline 80 & $\mathrm{n} / \mathrm{a}$ & - & 647,3752 & - & - & - & - \\
\hline 81 & $\mathrm{DG}^{*}$ & HMDB56204 & 655,4883 & 655,5272 & 632,5379 & $\mathrm{M}+\mathrm{Na}$ & $\mathrm{C}_{40} \mathrm{H}_{72} \mathrm{O}_{5}$ \\
\hline 82 & $\mathrm{DG}^{*}$ & HMDB56298 & 663,4551 & 663,4959 & 640,5066 & $\mathrm{M}+\mathrm{Na}$ & $\mathrm{C}_{41} \mathrm{H}_{68} \mathrm{O}_{5}$ \\
\hline 83 & $\mathrm{DG}^{*}$ & HMDB56037 & 675,5749 & 675,5898 & 652,6005 & $\mathrm{M}+\mathrm{Na}$ & $\mathrm{C}_{41} \mathrm{H}_{80} \mathrm{O}_{5}$ \\
\hline 84 & $\mathrm{DG}^{*}$ & HMDB07430 & 693,4931 & 693,5428 & 670,5536 & $\mathrm{M}+\mathrm{Na}$ & $\mathrm{C}_{43} \mathrm{H}_{74} \mathrm{O}_{5}$ \\
\hline 85 & $\mathrm{PC}^{*}$ & HMDB08519 & 892,6545 & 892,6790 & 891,6717 & $\mathrm{M}+\mathrm{H}$ & $\mathrm{C}_{52} \mathrm{H}_{94} \mathrm{NO}_{8} \mathrm{P}$ \\
\hline
\end{tabular}

Metabolites were annotated by library search (HMDB), accurate mass and isotopic abundance distribution; $m / z-$ mass-to-charge ratio; $\mathrm{n} / \mathrm{a}-$ not assigned; DG—-diacylglycerol; MG—-monoacylglycerol; LPA—lysophosphatidic acid; PA—-phosphatidic acid; LysoPC -lysophospholipid; PC—phosphatidylcholine; * — redundant masses with several candidates. 
creatine and leucine (MS/MS $20 \mathrm{eV}$ )

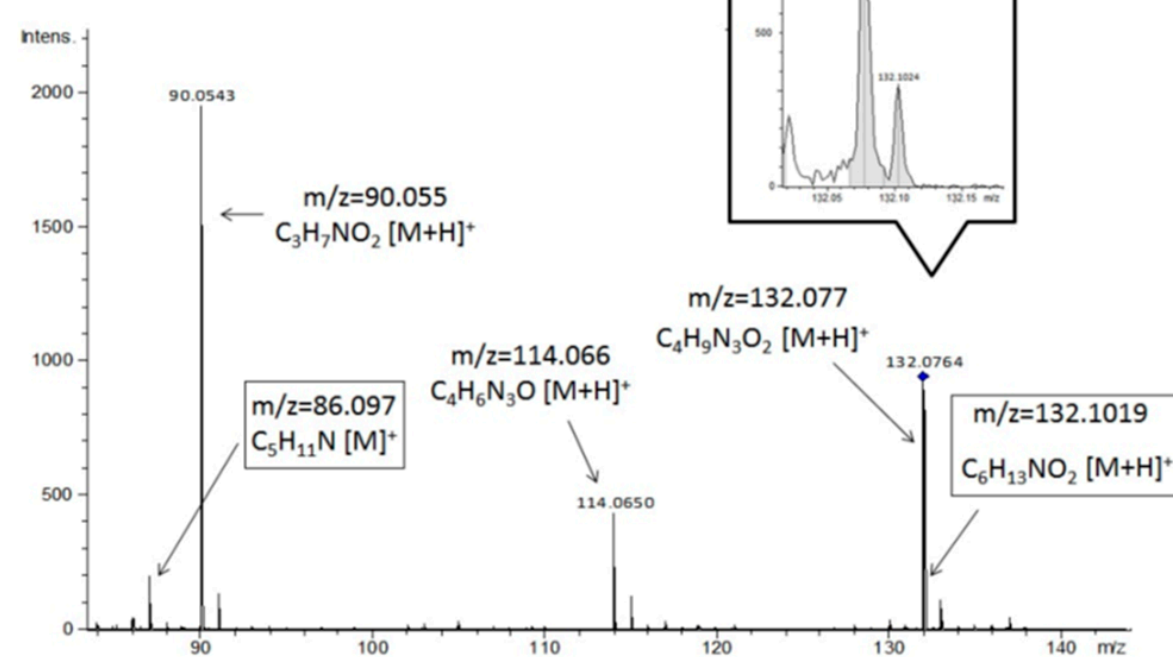

Figure 3. The results of MS/MS fragmentation of selected metabolites $(m / z-132,0777$ and $m / z-132,1024)$. MS/MS spectra obtained in positive ionization mode. Collision energy-20 eV. Reference $m / z$ value of fragments of leucine, creatine, chemical formula and ion type (taken from the public metabolite database) are also indicated in the figure.

Results of metabolites identification using MS/MS analysis are summarized in Table 2.

Table 2. Identification of selected metabolites by MS/MS fragmentation.

\begin{tabular}{|c|c|c|c|c|c|c|c|c|}
\hline \multirow[b]{2}{*}{ Metabolite } & \multicolumn{4}{|c|}{ Precursor Ion } & \multicolumn{4}{|c|}{ Product Ion } \\
\hline & $\begin{array}{c}\text { Registered } \\
m / z, \mathrm{Da}\end{array}$ & $\begin{array}{c}\text { Calculated } \\
m / z, \mathrm{Da}\end{array}$ & $\begin{array}{l}\text { Chemical } \\
\text { Formula }\end{array}$ & Ion Type & $\begin{array}{c}\text { Registered } \\
m / z, \mathrm{Da}\end{array}$ & $\begin{array}{c}\text { Reference } \\
m / z, \mathrm{Da}\end{array}$ & $\begin{array}{l}\text { Chemical } \\
\text { Formula }\end{array}$ & Ion Type \\
\hline \multirow{2}{*}{ leucine } & & & & & - & $44,0499 *$ & $\mathrm{C}_{2} \mathrm{H}_{5} \mathrm{~N}$ & {$[\mathrm{M}+\mathrm{H}]^{+}$} \\
\hline & & & & & - & 43,0546 * & $\mathrm{C}_{3} \mathrm{H}_{6}$ & {$[\mathrm{M}+\mathrm{H}]^{+}$} \\
\hline creatine & & & & & 90,0543 & $90,0552 *$ & $\mathrm{C}_{3} \mathrm{H}_{7} \mathrm{NO}_{2}$ & {$[\mathrm{M}+\mathrm{H}]^{+}$} \\
\hline \multirow[t]{3}{*}{ L-carnitine } & 162,1126 & 162,1125 & $\mathrm{C}_{7} \mathrm{H}_{15} \mathrm{NO}_{3}$ & {$[\mathrm{M}+\mathrm{H}]^{+}$} & 103,0402 & 103,039 * & $\mathrm{C}_{4} \mathrm{H}_{7} \mathrm{O}_{3}$ & {$[\mathrm{M}]^{+}$} \\
\hline & & & & & 102,0914 & 102,0913 * & $\mathrm{C}_{5} \mathrm{H}_{12} \mathrm{NO}$ & {$[\mathrm{M}]^{+}$} \\
\hline & & & & & 85,0312 & $85,0284 *$ & $\mathrm{C}_{4} \mathrm{H}_{4} \mathrm{O}_{2}$ & {$[\mathrm{M}+\mathrm{H}]^{+}$} \\
\hline
\end{tabular}

Identification was performed by comparing detected $m / z$ values of fragments (resulting from MS/MS fragmentation of selected metabolites) to corresponding $\mathrm{m} / \mathrm{z}$ value of the reference fragments of leucine, creatine, and l-carnitine from the public metabolite database; $m / z$-mass-to-charge ratio. A mass tolerance window-0,005 Da. *-the reference results of MS/MS fragmentation were taken from public metabolite database METLIN.

Thus the results of MS/MS fragmentation confirmed the results of the earlier identification.

The distribution of the relative intensity of the putative metabolites in the compared groups is demonstrated in Figure 4. Careful examination of selected metabolites allowed dividing the major part of them into several groups. The first group may be named as the "group of amino acids". A high level of some amino acids (valine, leucine, alanine, taurine, and hypotaurine) was observed in the samples related to negligible senescence (Figure 4 metabolites 1, 8, 11, 13, and 14). However, a high level of some of these metabolites was also registered in the samples related to gradual senescence. The second group is the "group of biogenic amines". A high level of spermidine was observed in the samples related to negligible senescence (Figure 4 metabolite 17). The third group of metabolites may 
be named as the "group of energy metabolism". Creatine, creatinine, carnitines, and the intermediates of the citric acid cycle may be associated with the group. A high level of creatine, creatinine, and L-carnitine is noted in the samples related to negligible senescence (Figure 4 metabolites 3, 4, 12), while the accumulation of medium and long-chain acylcarnitines and the intermediates of the citric acid cycle (fumarate, malate, alpha-ketoglutarate, and citrate) is observed in the samples related to rapid senescence (Figure 4 metabolites 39, 41, 42 48). The fourth group may be named as the "group of intermediates of sugar metabolism". There was an accumulation of the intermediates of sugar metabolism (maltose, lactate, and pyruvate) in the samples related to rapid senescence (Figure 4 metabolites 33, 34, 63). Finally, the fifth group is the "group of lipid metabolism". A high level of various lipid intermediates was observed in the samples related to rapid senescence.

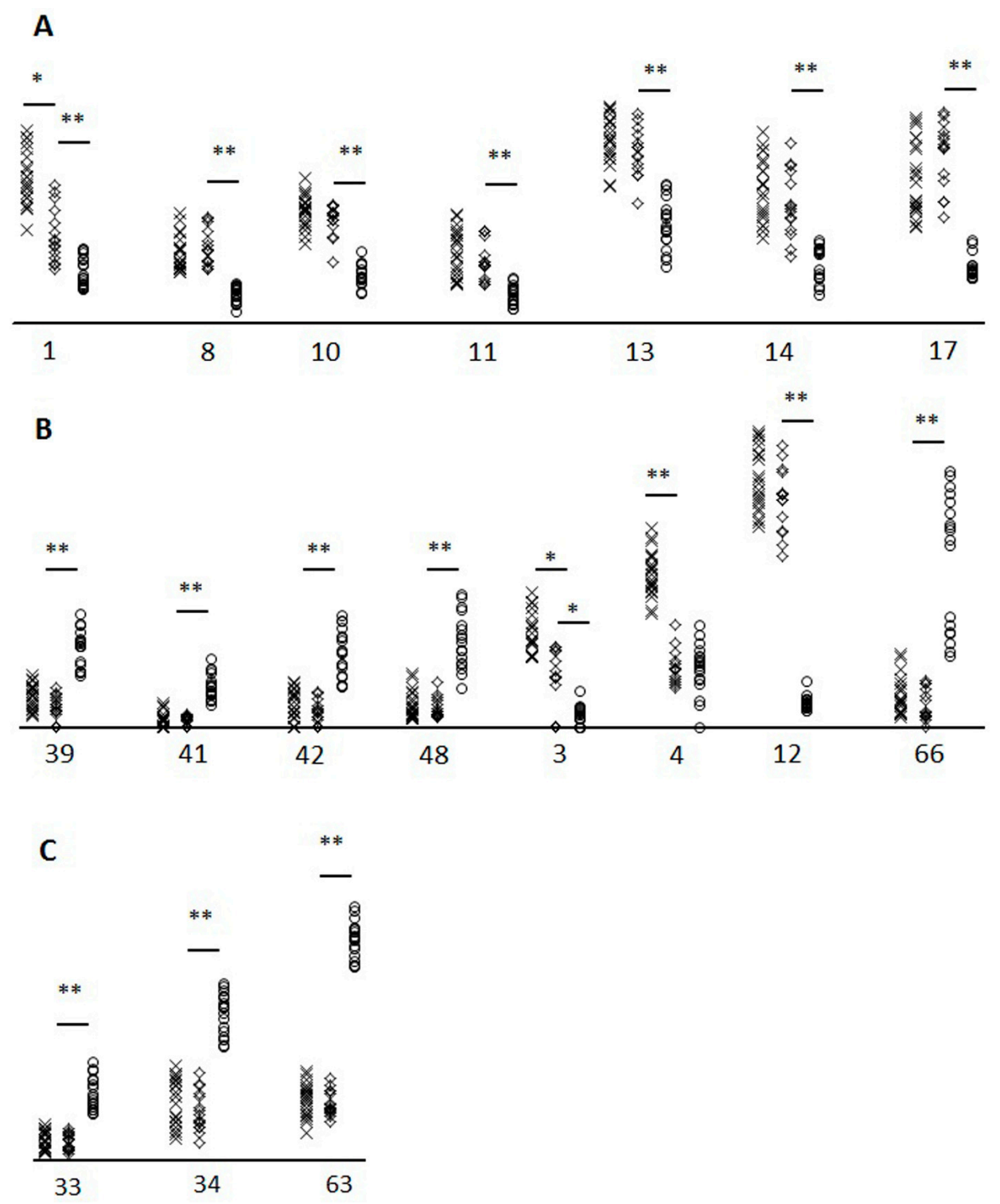

Figure 4. Results of the univariate statistical analysis identified metabolites with statistically significant differences among groups (negligible $-(\times)$, gradual $-(\diamond)$ and rapid senescence- $(O)$ ). A.-metabolites related to a "group of amino acids" and a "group of biogenic amines" (alanine, valine, leucine, taurine, hypotaurine, and spermidine); B.-metabolites related to a "group of energy metabolism" (creatine, creatinine, carnitines, fumarate, malate, alpha-ketoglutarate, and citrate); C.-metabolites related to a "group of intermediates of sugar metabolism" (maltose, lactate, and pyruvate). The scatter plots show the intensity (relative units) of identified metabolites in the three compared groups. $\left({ }^{* *}-p<0.01\right.$; * $-p<0.05$ ). Numbers are corresponded to ordinal metabolites numbers indicated in Table 1. 


\section{Discussion}

A method of comparative analysis is one of the universal approaches for the detection and identification of key components that are a source of heterogeneity between samples [17]. Fish are the ideal model for investigations of the biochemical basis of the aging process by the approach. The availability of a large number of similar physiological, biochemical, and histological characteristics between fish species enables one to minimize the list of features which should be analyzed to identify metabolites and pathways that are possibly associated with the aging process. Availability of a lot of fish species belonging to different types of aging enable to include several species in each analyzed group allowing to eliminate a various species-specific metabolic perturbations (only group-specific perturbations should be selected for subsequent analysis).

An opportunity to perform large-scale experiments is another one advantage of the experimental model with fish. Most of the fish organs (heart, excretory organs, digestive organs, etc.) are analogous to organs of other vertebrates [18]. This fact provides the possibility of translating the results onto processes in mammals. This study is a follow-up to a previously published investigation of blood metabolic profiles associated with the various ageing rate of fishes [19]. The research was focused on the analysis of metabolic compositions of fish muscle tissues for the identification of distinctive features between compared groups. A direct injection mass spectrometry (DIMS) approach was used in the study. Despite a large number of limitations (ion suppression, inability of isobars separation, etc.), until now DIMS has been a popular approach [20]. High throughput and reproducibility, wide metabolomic coverage (no loss of metabolites due to the application of any separation tools), and short analysis time are advantages of the DIMS method allow the improvement of the reliability and accuracy of the results of subsequent multivariate statistical analysis [20,21].

The largest number of identified metabolites belongs to lipids: a high level of storage lipids (tri- diand monoacylglycerols, fatty acids, cholesterol) is found in salmonids. Accumulation of distinct phospholipids is detected for in each compared group. There are many of external and internal factors (environment, diet, feeding regime and digestion, etc.) that can influence the fatty acids' compositions in lipids [22,23]. For example, it was demonstrated that the level of muscle fatty acids composition of the same fish species depends on habitat-independent environmental factors [24,25]. Most likely the revealed differences in abundance of lipids in the compared fish species are the result of the effect of such factors. Salmonids are classified as "fatty" fish species because they have a large amount of storage lipids in muscle compared to other fish species [26,27].

There is very little information about the effects and possible mechanisms of action of lipids on biological processes which can be associated with aging. In some studies related to the aging research, an increase or decrease of the level of distinct lipids with age is noted. Unfortunately, the mechanism of this accumulation or loss of the lipids is not specified.

The intensification of glycogenolysis and glycolysis is the most probable cause of accumulation of metabolites of the "group of intermediates of sugar metabolism" (maltose, lactate, and pyruvate), medium and long-chain acylcarnitines, and the intermediates of the citric acid cycle (fumarate, malate, alpha-ketoglutarate, and citrate) (Figure 4, metabolites 33, 34, 39, 41, 42, 48, and 63), which are observed in the samples of rapid aging fish [28-33]. Activation of these processes with a simultaneous decline in the creatine and creatinine levels in salmonids species (Figure 4, metabolites 3 and 12) is probably due to the intensive swimming of fish during the migration for spawning [34]. However, it is possible that the accumulation of the intermediates of glucose is a result of any other factor or the combined effect of several factors. For example, mitochondrial dysfunction leads to similar changes: intracellular accumulation of intermediates of the citric acid cycle, intermediates of glucose metabolism, etc. [32,35-37].

Amino acids and biogenic amines, a high level of some of which was observed in negligible senescent and gradually aging species (Figure 4, metabolites 1, 8, 11,13, and 14), exhibit a wide range of biological effects. Amino acids are one of the key elements of many cellular processes: differentiation and growth of skeletal muscles, osmoregulation, reproduction, immune response, and the precursors 
of biologically active compounds [38]. They are involved in antioxidant protection (taurine and hypotaurine) and energy metabolism (alanine, valine, and leucine), enhance protein synthesis and inhibit proteolysis (leucine and valine) [39-42]. A number of studies have noted that an increase in the level of amino acids and biogenic amines leads to a decrease of the development and expression rate of age-related pathologies as well as an extension of the activity period of the musculoskeletal system in mammalia [43]. Most likely, the action of amino acids and biogenic amines in fish muscles is similar. However, the pathways for fish have not been established yet [38].

Based on the observations mentioned above, we can conclude that the capacity of antioxidant protection, the productivity of anabolic processes and, possibly, the effectiveness of energetic metabolism in skeletal muscle tissue samples obtained from negligible senescent and gradually aging species are higher in comparison with similar processes in skeletal muscle tissue samples related to rapid aging. A decrease in the effectiveness of these processes or their damage may lead to a loss of muscle mass and strength with aging [44].

\section{Material and Methods}

\subsection{Muscle Sampling}

The samples of young, ready-for-reproduction adults (all of them had visible developing gonads) were used in our work: the first group of pike (N: 12; an average mass of $1.2 \pm 0.5 \mathrm{~kg}$ and body length $-55 \pm 7 \mathrm{~cm})$ and sterlet $(\mathrm{N}: 12 ; 1.5 \pm 0.3 \mathrm{~kg} ; 70 \pm 5 \mathrm{~cm})$, the second group of zander $(\mathrm{N}: 10$; $2.2 \pm 1.1 \mathrm{~kg} ; 50 \pm 14 \mathrm{~cm})$ and perch $(\mathrm{N}: 8 ; 0.13 \pm 0.07 \mathrm{~kg} ; 23 \pm 3 \mathrm{~cm})$, the third group-pink salmon $(\mathrm{N}: 10 ; 1.55 \pm 0.45 \mathrm{~g} ; 51 \pm 3 \mathrm{~cm})$ and chum salmon $(\mathrm{N}: 10 ; 3.1 \pm 1.3 \mathrm{~kg} ; 63 \pm 7 \mathrm{~cm})$. The ratio of males to females for each species was approximately 1:1. The age of each fish was determined by analyzing the growth rings on the scales [45]. The salmon samples were obtained from fish caught near Sakhalin Island (Russia); all others were obtained from fish caught in the Uglich Reservoir (Russia) during September 2014 and May-June 2015 (collection permits: no. 69201403 0722, no. 69201503 0683, and no. 69201603 0737, issued by the Federal Agency for Fisheries of the Russian Federation). The study was conducted in accordance with the Declaration of Helsinki.

Samples of muscles (about $0.1 \mathrm{~g}$ ) were cut off from the spinal area. Visually, the samples did not contain any inclusions of other tissues. In order to better reflect the original metabolic state, the samples were immediately frozen and stored at $-80^{\circ} \mathrm{C}$ before the analysis [46].

\subsection{Extraction Method and Sample Preparation}

The extraction methods used in this work were adapted from previously published investigations $[47,48]$ with modifications. Frozen tissue samples were lyophilized overnight. Then, each sample was weighed, homogenized (Bandelin Sonopuls HD 2200, Sigma-Aldrich, St. Louis, MO, USA ), divided into Eppendorf vials and extracted using $20 \mathrm{~mL} / \mathrm{g}$ (dry mass) of solution ethanol-water (4:1), precooled to $4{ }^{\circ} \mathrm{C}$. After that, the suspension was maintained at $4{ }^{\circ} \mathrm{C}$ for $60 \mathrm{~min}$ (incubation period) and strongly vortexed for $30 \mathrm{~s}$ (10 times), being placed on ice in between. All reagents were of analytical grade and were used without further purification. After centrifugation $(15,000 \mathrm{~g} ; 15$ $\min ; 4^{\circ} \mathrm{C}$ ), the supernatant was collected, distributed into Eppendorf vials (Eppendorf, Hamburg, Germany) and stored at $-80^{\circ} \mathrm{C}$ before analysis. Before mass spectrometry analysis to each aliquot (10 $\mu \mathrm{L}$ ) of the supernatant, the fifty volumes of $90 \%$ methanol (Fluka, Munich, Germany) with $0.1 \%$ formic acid (Fluka, Munich, Germany) was added to obtain the analyzed solution [49].

\subsection{Mass Spectrometry Analysis}

The samples were analyzed using a hybrid quadrupole time-of-flight mass spectrometer (micrOTOFQ, Bruker Daltonics, Billerica, MA, USA) equipped with electrospray ionization (ESI) source. The mass spectrometer was set up for priority detection of ions with the mass-to-charge ratio $(\mathrm{m} / \mathrm{z})$ range from 80 to 1000 and mass accuracy up to 5 parts per million (ppm). ES Tuning 
Mix (Agilent Technologies, Santa Clara, CA, USA) was used for calibration of the mass spectrometer. The spectra were recorded in the positive ion charge detection mode. The samples were injected into the ESI source using a glass syringe (Hamilton Bonaduz AG, Bonaduz, Switzerland) connected to a syringe injection pump (KD Scientific, Holliston, MA, USA). The flow rate of samples to the ionization source was $180 \mu \mathrm{L} / \mathrm{h}$, and the samples were injected in a randomized order [49]. More detailed identification of the several selected metabolites was produced through ion fragmentation by collision-induced dissociation (CID) of the ions of interest (precursor ion). Ultra-pure nitrogen was used as collision gas. The fragmentation of the metabolites was performed at different collision energies (10 and $20 \mathrm{eV}$ ). The mass spectra were recorded using DataAnalysis version 3.4 (Bruker Daltonics, Germany) to summarize one-minute signals.

\subsection{Data Analysis}

Data analysis was used for the preliminary peak selection and recalibration of the spectra. The selection parameters were as follows: peak width -5 , signal-to-noise ratio-2, relative and absolute threshold intensity $-0.05 \%$ and 100 respectively. Alignment of mass spectrum peaks, removal of low-informative peaks, and data correction to address ionic inconsistency in samples were performed by using the self-made algorithm in Excel. Two peaks were considered to be related to the same metabolite if the mass difference did not exceed $0.05 \mathrm{Da}$. All peaks' intensity and area values were normalized by the internal standard (IS) losartan $\left(\mathrm{C}_{22} \mathrm{H}_{23} \mathrm{ClN}_{6} \mathrm{O}, m / z=423.169\right)$ concentration levels.

Analysis of acquired metabolite profiling data was performed by means of Principal Component Analysis (PCA) implemented in the software package ProfileAnalysis version 3.4 (Bruker Daltonics, Germany). Statistically significant differences between the study groups were evaluated using the Kruskal-Wallis H test implemented in the software package Statistica (StatSoft Inc., Tulsa, OK, USA).

\subsection{Mass Spectra Peak Identification}

The basic approach for identification of the selected peaks with clear isotope patterns consisted in searching of annotated metabolites, which had the closest $m / z$ values to those detected in the spectra [50]. The following reference databases were used: Human Metabolome DataBase (HMDB) (http:/ / www.hmbd.ca), METLIN (http:/ / metlin.scripps.edu), and LIPID MAPS (www.lipidmaps. org). A mass tolerance window was $0.05 \mathrm{Da}$. Several additional steps were taken to minimize misidentification. Peaks of parental ion and possible adducts of suppositional metabolites in the spectra were found. Next, comparative analysis of isotope patterns of the metabolites or their possible adducts in the spectra with their theoretical isotope patterns was performed [50]. Theoretical isotope patterns for each of the metabolites and adducts were produced using Isotope Pattern Calculator (Bruker Daltonics, Germany). Tandem mass spectrometry (MS/MS) was applied for more specific identification of several metabolites. In this case, identification was performed by comparing the MS/MS spectra obtained at different collision energies in positive ionization modes with the reference MS/MS spectra from the public metabolite database (METLIN). A mass tolerance window, in this case, was $0.005 \mathrm{Da}$.

\section{Conclusions}

In summary, a wide range of metabolites that belong to different classes was detected in muscles of fish with different lifespan. Applications of metabolic profiling in combination with statistical analyses allowed to identify the group-specific features. The obtained results made it possible to suggest the biochemical pathways involving the identified metabolites and, perhaps, associated with the rate of aging. Utilization of these results may enhance our knowledge of aging processes, facilitate the development of new rational approaches to prevent or even delay age-associated alterations in muscle, and hence improve health lifespan. 
Author Contributions: Conceptualization, D.L.M., M.V.M., P.G.L. and A.I.A.; methodology, D.L.M., M.V.M. and P.G.L.; software, D.L.M. and O.P.T. validation, D.L.M., K.V.Z. and M.V.M.; formal analysis, D.L.M. and O.P.T.; investigation, D.L.M., O.P.T., A.N.M., K.V.Z., K.V.N., V.I.N. and N.F.B.; resources, D.L.M., A.N.M., K.V.Z., K.V.N., V.I.N. and N.F.B.; data curation, D.L.M. and O.P.T.; writing-original draft preparation, D.L.M.; writing-review and editing, D.L.M., M.V.M. and P.G.L.; visualization, D.L.M.; supervision, D.L.M., M.V.M., P.G.L. and A.I.A.; project administration, D.L.M., M.V.M. and P.G.L.; funding acquisition, M.V.M., P.G.L. and A.I.A.

Funding: The work was done within the framework of the State Academies of Sciences Fundamental Scientific Research Program for 2013-2020. Mass spectrometry measurements were performed using the equipment of "Human Proteome" Core Facilities of the Institute of Biomedical Chemistry (Russia).

Conflicts of Interest: The authors declare no conflict of interest.

Ethical Approval: All applicable international, national, and/or institutional guidelines for the care and use of animals were followed.

\section{References}

1. Finch, C.E.; Austad, S.N. History and prospects: Symposium on organisms with slow aging. Exp. Gerontol. 2001, 36, 593-597. [CrossRef]

2. Valdesalici, S.; Cellerino, A. Extremely short lifespan in the annual fish Nothobranchius furzeri. Proc. R. Soc. B Biol. Sci. 2003, 270, S189-S191. [CrossRef] [PubMed]

3. Finch, C. Longevity, Senescence, and the Genome; University of Chicago Press: Chicago, IL, USA, 1990.

4. Patnaik, B.K.; Mahapatro, N.; Jena, B.S. Ageing in fishes. Gerontology 1994, 40, 113-132. [CrossRef]

5. Craig, C.; Kipling, J.F. Reproduction effort versus the environment; case histories of Windermere perch, Perca fluviatilis L., and pike, Esox lucius L. J. Fish Biol. 1983, 22, 713-727. [CrossRef]

6. Kirczuk, L.; Domagała, J.; Pilecka-Rapacz, M. Annual Developmental Cycle of Gonads of European Perch Females (Perca fluviatilis L.) from Natural Sites and a Canal Carrying Post-cooling Water from the Dolna Odra Power Plant (NW Poland). Folia Biol. 2015, 63, 85-93. [CrossRef]

7. Gorbunova, V.; Seluanov, A.; Zhang, Z.; Gladyshev, V.N.; Vijg, J. Comparative genetics of longevity and cancer: Insights from long-lived rodents. Nat. Rev. Genet. 2014, 15, 531-540. [CrossRef] [PubMed]

8. Selman, C.; Withers, D.J. Mammalian models of extended healthy lifespan. Philos. Trans. R. Soc. Lond. B. Biol. Sci. 2011, 366, 99-107. [CrossRef] [PubMed]

9. Moskalev, A.A.; Pasyukova, E.G. From theories of aging to anti-aging interventions. Front. Genet. 2014, 5, 276. [CrossRef]

10. Rosenberg, I.H. Sarcopenia: Origins and clinical relevance. Clin. Geriatr. Med. 2011, 27, 337-339. [CrossRef]

11. Baumgartner, R.N.; Koehler, K.M.; Gallagher, D.; Romero, L.; Heymsfield, S.B.; Ross, R.R.; Garry, P.J.; Lindeman, R.D. Epidemiology of sarcopenia among the elderly in New Mexico. Am. J. Epidemiol. 1998, 147, 755-763. [CrossRef] [PubMed]

12. Melton, L.J.; Khosla, S.; Riggs, B.L. Epidemiology of sarcopenia. Mayo Clin. Proc. 2000, 75, S10-S13.

13. Jeromson, S.; Gallagher, I.J.; Galloway, S.D.R.; Hamilton, D.L. Omega-3 fatty acids and skeletal muscle health. Mar. Drugs 2015, 13, 6977-7004. [CrossRef] [PubMed]

14. Payne, B.A.I.; Chinnery, P.F. Mitochondrial dysfunction in aging: Much progress but many unresolved questions. Biochim. Biophys. Acta Bioenerg. 2015, 1847, 1347-1353. [CrossRef]

15. Deberardinis, R.J.; Thompson, C.B. Cellular metabolism and disease: What do metabolic outliers teach us? Cell 2012, 148, 1132-1144. [CrossRef] [PubMed]

16. Dunn, W.B.; Erban, A.; Weber, R.J.M.; Creek, D.J.; Brown, M.; Breitling, R.; Hankemeier, T.; Goodacre, R.; Neumann, S.; Kopka, J.; et al. Mass appeal: Metabolite identification in mass spectrometry-focused untargeted metabolomics. Metabolomics 2013, 9, 44-66. [CrossRef]

17. Kahwati, L.; Jacobs, S.; Kane, H.; Lewis, M.; Viswanathan, M.; Golin, C.E. Using qualitative comparative analysis in a systematic review of a complex intervention. Syst. Rev. 2016, 5, 82. [CrossRef] [PubMed]

18. Gilbert, M.J.H.; Zerulla, T.C.; Tierney, K.B. Zebrafish (Danio rerio) as a model for the study of aging and exercise: Physical ability and trainability decreases with age. Exp. Gerontol. 2014, 50, 106-113. [CrossRef]

19. Trifonova, O.P.; Maslov, D.L.; Mikhailov, A.N.; Zolotarev, K.V.; Nakhod, K.V.; Nakhod, V.I.; Belyaeva, N.F.; Mikhailova, M.V.; Lokhov, P.G.; Archakov, A.I.; et al. Comparative Analysis of the Blood Plasma Metabolome of Negligible, Gradual and Rapidly Ageing Fishes. Fishes 2018, 3, 46. [CrossRef] 
20. Cajka, T.; Danhelova, H.; Vavrecka, A.; Riddellova, K.; Kocourek, V.; Vacha, F.; Hajslova, J. Evaluation of direct analysis in real time ionization-mass spectrometry (DART-MS) in fish metabolomics aimed to assess the response to dietary supplementation. Talanta 2013, 115, 263-270. [CrossRef] [PubMed]

21. Dettmer, K.; Aronov, P.A.; Hammock, B.D. Mass Spectrometry-Based Metabolomics. Mass Spectrom. Rev. 2007, 26, 51-78. [CrossRef]

22. Sérot, T.; Gandemer, G.; Demaimay, M. Lipid and fatty acid compositions of muscle from farmed and wild adult turbot. Aquac. Int. 1998, 6, 331-343. [CrossRef]

23. Megdal, P.A.; Craft, N.A.; Handelman, G.J. A simplified method to distinguish farmed (Salmo salar) from wild salmon: Fatty acid ratios versus astaxanthin chiral isomers. Lipids 2009, 44, 569-576. [CrossRef] [PubMed]

24. Özogul, Y.; Özogul, F. Fatty acid profiles of commercially important fish species from the Mediterranean, Aegean and Black Seas. Food Chem. 2007, 100, 1634-1638. [CrossRef]

25. Özogul, Y.; Özogul, F.; Alagoz, S. Fatty acid profiles and fat contents of commercially important seawater and freshwater fish species of Turkey: A comparative study. Food Chem. 2007, 103, 217-223. [CrossRef]

26. Jobling, M.; Johansen, S.J.S.; Foshaug, H.; Burkow, I.C.; Jørgensen, E.H. Lipid dynamics in anadromous Arctic charr, Salvelinus alpinus (L.): Seasonal variations in lipid storage depots and lipid class composition. Fish Physiol. Biochem. 1998, 18, 225-240. [CrossRef]

27. Josrgensen, E.H.; Johansen, S.J.S.; Jobling, M. Seasonal patterns of growth, lipid deposition and lipid depletion in anadromous Arctic charr. J. Fish Biol. 1997, 51, 312-326. [CrossRef]

28. Hiatt, W.R.; Regensteiner, J.G.; Wolfel, E.E.; Ruff, L.; Brass, E.P. Carnitine and acylcarnitine metabolism during exercise in humans. Dependence on skeletal muscle metabolic state. J. Clin. Investig. 1989, 84, 1167-1173. [CrossRef]

29. Sabatine, M.S.; Liu, E.; Morrow, D.A.; Heller, E.; McCarroll, R.; Wiegand, R.; Berriz, G.F.; Roth, F.P.; Gerszten, R.E. Metabolomic Identification of Novel Biomarkers of Myocardial Ischemia. Circulation 2005, 112, 3868-3875. [CrossRef]

30. Koves, T.R.; Ussher, J.R.; Noland, R.C.; Slentz, D.; Mosedale, M.; Ilkayeva, O.; Bain, J.; Stevens, R.; Dyck, J.R.B.; Newgard, C.B.; et al. Mitochondrial overload and incomplete fatty acid oxidation contribute to skeletal muscle insulin resistance. Cell Metab. 2008, 7, 45-56. [CrossRef]

31. Lehmann, R.; Zhao, X.; Weigert, C.; Simon, P.; Fehrenbach, E.; Fritsche, J.; Machann, J.; Schick, F.; Wang, J.; Hoene, M.; et al. Medium chain acylcarnitines dominate the metabolite pattern in humans under moderate intensity exercise and support lipid oxidation. PLoS ONE 2010, 5, e11519. [CrossRef] [PubMed]

32. Houtkooper, R.H.; Argmann, C.; Houten, S.M.; Cantó, C.; Jeninga, E.H.; Andreux, P.A.; Thomas, C.; Doenlen, R.; Schoonjans, K.; Auwerx, J. The metabolic footprint of aging in mice. Sci. Rep. 2011, 1, 134. [CrossRef]

33. Gumucio, J.P.; Mendias, C.L. Atrogin-1, MuRF-1, and sarcopenia. Endocrine 2013, 43, 12-21. [CrossRef] [PubMed]

34. McCommis, K.S.; Finck, B.N. Mitochondrial pyruvate transport: A historical perspective and future research directions. Biochem. J. 2015, 466, 443-454. [CrossRef]

35. Darras, B.T.; Friedman, N.R. Metabolic myopathies: A clinical approach; part I. Pediatr. Neurol. 2000, 22, 87-97. [CrossRef]

36. Baraibar, M.A.; Hyzewicz, J.; Rogowska-Wrzesinska, A.; Bulteau, A.-L.; Prip-Buus, C.; Butler-Browne, G.; Friguet, B. Impaired energy metabolism of senescent muscle satellite cells is associated with oxidative modifications of glycolytic enzymes. Aging 2016, 8, 3375-3389. [CrossRef]

37. Wan, Q.-L.; Shi, X.; Liu, J.; Ding, A.-J.; Pu, Y.-Z.; Li, Z.; Wu, G.-S.; Luo, H.-R. Metabolomic signature associated with reproduction-regulated aging in Caenorhabditis elegans. Aging 2017, 9, 447-474. [CrossRef] [PubMed]

38. Li, P.; Mai, K.; Trushenski, J.; Wu, G. New developments in fish amino acid nutrition: Towards functional and environmentally oriented aquafeeds. Amino Acids 2009, 37, 43-53. [CrossRef] [PubMed]

39. Kimball, S.R.; Jefferson, L.S. Signaling pathways and molecular mechanisms through which branched-chain amino acids mediate translational control of protein synthesis. J. Nutr. 2006, 136, 227S-231S. [CrossRef] [PubMed]

40. Newgard, C.B.; An, J.; Bain, J.R.; Muehlbauer, M.J.; Stevens, R.D.; Lien, L.F.; Haqq, A.M.; Shah, S.H.; Arlotto, M.; Slentz, C.A.; et al. A branched-chain amino acid-related metabolic signature that differentiates obese and lean humans and contributes to insulin resistance. Cell Metab. 2009, 9, 311-326. [CrossRef] [PubMed] 
41. Miyazaki, T.; Honda, A.; Ikegami, T.; Matsuzaki, Y. The role of taurine on skeletal muscle cell differentiation. Adv. Exp. Med. Biol. 2013, 776, 321-328. [PubMed]

42. Spriet, L.L.; Whitfield, J. Taurine and skeletal muscle function. Curr. Opin. Clin. Nutr. Metab. Care 2015, 18, 96-101. [CrossRef]

43. Minois, N. Molecular basis of the "anti-aging" effect of spermidine and other natural polyamines-A mini-review. Gerontology 2014, 60, 319-326. [CrossRef] [PubMed]

44. Glover, E.I.; Phillips, S.M.; Oates, B.R.; Tang, J.E.; Tarnopolsky, M.A.; Selby, A.; Smith, K.; Rennie, M.J. Immobilization induces anabolic resistance in human myofibrillar protein synthesis with low and high dose amino acid infusion. J. Physiol. 2008, 586, 6049-6061. [CrossRef] [PubMed]

45. Tesch, F.W. Age and Growth. In Methods for Assessment of Fish Production in Fresh Waters; Ricker, W.E., Ed.; Blackwell Sci. Pub.: Oxford, UK, 1968; pp. 93-123.

46. Rammouz, R.E.; Létisse, F.; Durand, S.; Portais, J.C.; Moussa, Z.W.; Fernandez, X. Analysis of skeletal muscle metabolome: Evaluation of extraction methods for targeted metabolite quantification using liquid chromatography tandem mass spectrometry. Anal. Biochem. 2010, 398, 169-177. [CrossRef] [PubMed]

47. Van Scoy, A.R.; Yu Lin, C.; Anderson, B.S.; Philips, B.M.; Martin, M.J.; McCall, J.; Todd, C.R.; Crane, D.; Sowby, M.L.; Viant, M.R.; et al. Metabolic responses produced by crude versus dispersed oil in Chinook salmon pre-smolts via NMR-based metabolomics. Ecotoxicol. Environ. Saf. 2010, 73, 710-717. [CrossRef] [PubMed]

48. Lin, C.Y.; Wu, H.; Tjeerdema, R.S.; Viant, M.R. Evaluation of metabolite extraction strategies from tissue samples using NMR metabolomics. Metabolomics 2007, 3, 55-67. [CrossRef]

49. Lokhov, P.G.; Kharybin, O.N.; Archakov, A.I. Diagnosis of lung cancer based on direct-infusion electrospray mass spectrometry of blood plasma metabolites. Int. J. Mass Spectrom. 2012, 309, 200-205. [CrossRef]

50. Lynn, K.-S.; Cheng, M.-L.; Chen, Y.-R.; Hsu, C.; Chen, A.; Lih, T.M.; Chang, H.-Y.; Huang, C.; Shiao, M.-S.; Pan, W.-H.; et al. Metabolite identification for mass spectrometry-based metabolomics using multiple types of correlated ion information. Anal. Chem. 2015, 87, 2143-2151. [CrossRef] 